\title{
Liability for Misrepresentation - European Lessons on Causation from the Netherlands
}

\author{
by
}

BAS J. DE JONG ${ }^{1}$

Listed companies may be liable to investors for misrepresentation. A causal connection between the investor's alleged harm and the misstatement or omission will need to be established for a successful damage claim. This article addresses causation, specifically the causal connection between the misstatement (or omission) and the investment decision. Proving this causal connection is often problematic, which raises the question how investors can be effectively protected without inviting excessive litigation. Recently, the Dutch Supreme Court has accepted an indirect causal connection as sufficient and has adopted a presumption on behalf of investors on favorable terms in a prospectus liability case. A showing of a material misstatement by investors activates the presumption. The Dutch Supreme Court justifies this by reference to the Prospectus Directive, which it interprets as requiring an effective protection of (potential) investors. The influence of the Prospectus Directive on the law of causation can be relevant for other European jurisdictions as well. The approach to adopt a presumption based on European disclosure directives could extend beyond prospectus liability cases to all lawsuits alleging misrepresentation on the secondary market. These developments are discussed and a comparison is made between the law of the Netherlands, the US and Germany.

Table of Contents

ECFR 2011, 352-375

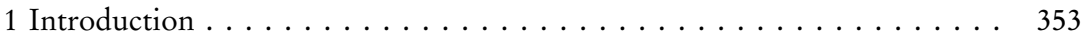

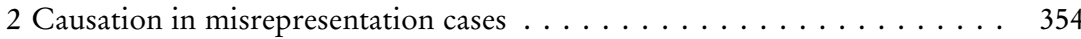

2.1 The general framework: cause in fact and legal cause . . . . . . . . 354

2.2 The causal connection between the misstatement and the investment

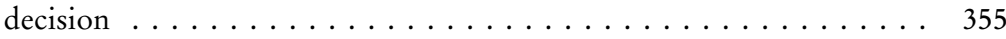

3 Effective protection (I): how indirect may the causal connection be? . . . 356

3.1 Dutch law . . . . . . . . . . . . . . . . . 356

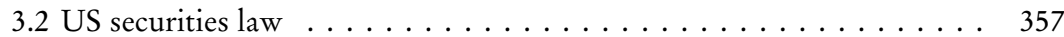

3.3 German law. . . . . . . . . . . . . . . . . . . . . 359

3.4 Comparative conclusions and comments . . . . . . . . . . 361

4 Effective protection (II): applying a presumption of proof . . . . . . . 364

4.1 Dutch law . . . . . . . . . . . . . . . . . . . . . . . 364

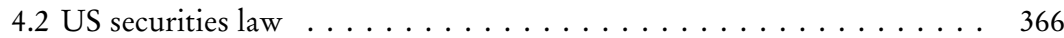

1 Dr. Bas J. de Jong is Assistant Professor of company law at Radboud University Nijmegen, the Netherlands (b.dejong@jur.ru.nl). He was a Fulbright visiting scholar at Columbia Law School in New York. 
4.3 German law. . . . . . . . . . . . . . . . . . . . . 369

4.4 Comparative conclusions and comments . . . . . . . . . . . . 371

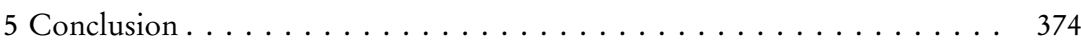

\section{Introduction}

Listed companies may be liable to investors for misrepresentation. Lawsuits alleging misrepresentation are common in both Europe and the United States. In European jurisdictions, misrepresentation may be the result of the publication of a misleading prospectus, misleading (annual, half-yearly or quarterly) financial reports, misleading interim management statements and other ad hoc statements, or a failure to disclose inside information which directly concerns the company. A successful damage claim requires, among other things, that causation between a misstatement (or omission) and the alleged harm is established. Causation is a complicated subject, especially when applied to misrepresentation claims. ${ }^{2}$

This article addresses causation, specifically the causal connection between the misstatement (or omission) and the investment decision. Proving this causal connection is often problematic, which raises the question how investors can be effectively protected without inviting vexatious litigation and an undesirable expansion of liability for listed companies. The Dutch Supreme Court recently handed down an important decision on causation in the World Online case $^{3}$, dealing with prospectus liability. As will become clear later in this article, an indirect causal connection was considered sufficient and - more importantly - a presumption of a causal connection was adopted on behalf of investors on favorable terms. A showing of a material misstatement is sufficient to activate the presumption. It is very interesting that the Dutch Supreme Court justifies this by reference to the Prospectus Directive ${ }^{4}$ of the European Union. According to the court, this directive requires an effective protection of investors under the rules of national law. I believe the influence of the Prospectus Directive on substantive law of causation can be relevant for other member states of the European Union as well. Even if legislation or case law may formally require investors to prove causation, presumptions may assist them considerably. Moreover, the approach could extend beyond pros-

2 See e.g. the American case Suez Equity Investors, L.P. v. Toronto-Dominion Bank, 250 F.3d 87, at 95-97 (2d Cir. 2001) ("It is settled that causation under federal securities laws is two-pronged: a plaintiff must allege both transaction causation ... and loss causation ... Because these concepts are somewhat elusive, they are the subject of extensive scholarly and judicial comment.").

3 Hoge Raad 27 november 2009, JOR 2010/43 (VEB e.a./World Online e.a.).

4 Council Directive (EC) 2003/71 [2003] OJ L345/64. 
pectus liability cases to all lawsuits alleging misstatements on the secondary market, because disclosure requirements on the secondary market are also based on European directives aiming at investor protection.

I first discuss causation in misrepresentation cases in general $(\mathbb{2} 2)$. As we will see, case law usually requires a causal connection between a misstatement and the investment decision. I address two more specific questions with respect to this causal connection: how indirect may it be $(\mathbb{S} 3)$ ?; and how should the burden of proof be divided between investors and the issuer $(\$ 4)$ ? The answer to these related questions is very important for the effectiveness of the protection of (potential) investors. A comparison will be made between the law of the Netherlands, the United States and Germany.

\section{Causation in misrepresentation cases}

\subsection{The general framework: cause in fact and legal cause}

Under the law of most jurisdictions, establishing causation is a two-step procedure. In the Principles of European Tort Law (PETL) the first step is indicated as the sine qua non rule (art. 3:101) and the second step as the scope of liability (art. 3:201)..$^{5}$ A different terminology may also be used in jurisdictions, such as cause in fact or "but for" causation for the first step, and legal or proximate cause for the second step. ${ }^{6}$

The first step consists of the inquiry whether the tort was a necessary condition (condition sine qua non) for the harm of the injured party: would the harm also have resulted in the hypothetical case that the tort would not have occurred? Often this inquiry involves uncertainty about the hypothetical state of the world that would have occurred absent the tort. If the injured party has the burden of proof with respect to cause in fact, then he may face a difficult hurdle. Courts may accept a reasonable degree of certainty as sufficient, or use techniques such as presumptions to relieve the investor's burden of proof.

The second step deals with the question whether and to what extent the harm may be attributed to the tortfeasor. The answer to this question may depend on factors such as: (i) the foreseeability of the damage to a reasonable person at the time of the activity, (ii) the nature and the value of the protected interest, (iii) the basis of liability, (iii) the extent of the ordinary risks of life, and (iv) the protective purpose of the rule that has been violated (see art. 3:201 PETL).

5 See European Group on Tort Law, Principles of European Tort Law (Springer 2005).

6 Thomas Lee Hazen, Hazen's Treatise on the Law of Securities Regulations (6th edn Thomson West) $\$ 12.11[1]$. 


\subsection{The causal connection between the misstatement and the investment decision}

How is the general framework of causation applied to misrepresentation cases? In answering this question, I will first focus on the law of the Netherlands, in particular the recent World Online decision ${ }^{7}$ on prospectus liability. Comparative analysis with the law of the United States and Germany is conducted in the following paragraphs.

In the Netherlands, there are no specific statutory provisions on causation in misrepresentation cases. Recently, the Dutch Supreme Court provided some guidance in the World Online decision. World Online was an internet provider which obtained a listing in 2000. It was accused of issuing a misleading prospectus for its initial public offering and publishing misleading ad hoc statements.

In his concluding argument to the Supreme Court, the Advocate General Levinus Timmerman stated that in prospectus liability cases, cause in fact requires a causal connection between the misstatement and the investment decision. He compared this to the Anglo-American concept of reliance ${ }^{8}$ and the German concept of haftungsbegründende Kausalität ${ }^{9} .{ }^{10}$ The Dutch Supreme Court agrees with the Advocate General that a causal connection between the misstatement and the investment decision is required. It does not offer any guidance on other aspects of causality, such as the question whether it needs to be shown that the share price was distorted by the misstatement, and whether and to what extent the harm may be attributed to the party responsible for the misrepresentation (legal cause).

In the remainder of this paper, I would like to address two related issues with respect to the requirement of a causal connection between the misstatement and the investment decision. The first is how the causal connection can be shown (see infra $\$ 3$ ). Is it necessary that the investor has read the information document himself (which will often not be the case), or is a more indirect causal connection sufficient? This is also a normative question, to be analyzed under the heading of legal cause or the scope of liability. A second issue is how

7 Hoge Raad 27 november 2009, JOR 2010/43 (VEB e.a./World Online e.a.).

8 See Thomas Lee Hazen, Hazen's Treatise on the Law of Securities Regulations (6th edn Thomson West), $\mathbb{\$} 7.3, \mathbb{\$} 12.10$.

9 See HD Assmann and R Schütze, Handbuch des Kapitalanlagerechts (CH Beck 2007) $\$ 6 \mathrm{Rn} .175 \mathrm{ff}$.

10 He also identified a second link of cause in fact, namely the causal connection between the drop in the stock price after disclosure of the truth. He compared this to the American concept of loss causation and the German concept of haftungsausfüllende Kausalität. 
the burden of proof with respect to the causal connection should be divided (see infra \$4). The discussion of these two issues will cover both prospectus liability cases and other secondary market liability claims.

An important theme in the next two paragraphs will be effective investor protection. Requiring each investor to show a direct causal connection is in practice very likely to shut the door to a successful damage claim. It would also hinder procedures aiming at collective redress by investors or their representative organizations. As we will see, the European disclosure directives (the Prospectus Directive ${ }^{11}$, the Transparency Directive ${ }^{12}$ and the Market Abuse Directive ${ }^{13}$ ) can be interpreted as requiring effective investor protection under the rules of national law (see infra $\$ 4.1$ ).

\section{Effective protection (I): how indirect may the causal connection be?}

\subsection{Dutch law}

As I have observed, the Dutch Supreme Court requires a causal connection between the misleading prospectus and the investment decision in the World Online decision ${ }^{14}$. However, the Supreme Court acknowledges that the investor may not actually have read the prospectus. The influence of the misstatement on the investor can also have been indirect, through advices or prevailing opinions in the market, which in turn were brought into existence by the misleading statement. It seems that the Supreme Court accepts this indirect influence as a sufficient causal connection. Finally, it is relevant to note that the Supreme Court adopted a presumption of the causal connection between the misstatement and the investment decision, based in part on the Prospectus Directive (see infra $\ 4.1$ ). This means that the issuer will have to show that the investor did not rely directly or indirectly (through an advisor or prevailing opinions in the market) on the misleading prospectus at the time of purchase.

With respect to lawsuits alleging misleading statements or omissions on the secondary market, it is likely that the Supreme Court will also in principle require a causal connection between the misstatement/omission and the investment decision. Equally, such a causal connection can probably be adopted if the investor only relied on the misstatement through advices or prevailing opinions in the market. It is uncertain whether a presumption of causation will be adopted in these cases, but this is certainly possible (see infra $\$ 4.1$ ).

11 Council Directive (EC) 2003/71 [2003] OJ L345/64.

12 Council Directive (EC) 2004/109 [2004] OJ L390/38.

13 Council Directive (EC) 2003/6 [2003] OJ L96/16.

14 Hoge Raad 27 november 2009, JOR 2010/43 (VEB e.a./World Online e.a.). 


\subsection{US securities law}

In the United States, claims with respect to a misleading registration statement ${ }^{15}$ can be based on s. 11 Securities Act 1933. In the United States an investor does not need to show reliance in case of a damage claim based on s. 11 Securities Act 1933. However, an investor who knew of the untruth or omission has no claim. Looking beyond how the burden of proof is allocated, it therefore seems that any form of indirect reliance is enough for a damage claim. ${ }^{16}$ If the investor acquires the security after the issuer has made generally available to its security holders an earning statement covering a period of at least twelve months beginning after the effective date of the registration statement, the right of recovery shall be conditioned on proof of reliance. However, reliance may be established without proof of the reading of the registration statement. ${ }^{17}$ If investors sue the issuer on the basis of s. 12(a) Securities Act 1933 for publishing a misleading prospectus, reliance is also not an element of the claim.

Claims may also be based on $\$ 10(b)$ of the Securities Exchange Act 1934 and SEC Rule 10b-5 promulgated thereunder. Usually, this is the basis for claims with respect to securities trading on the secondary market, but the claim may also deal with a misleading prospectus. Reliance is an element of the claim, ${ }^{18}$ although commentators have argued that this is not obvious. ${ }^{19}$ The test is whether the investor has relied on the misleading information at the moment he acquired the shares, in the sense that he would not have acted (i.e. purchased) had he known the truth. ${ }^{20}$ In the seminal case Basic v. Levinson ${ }^{21}$, the

15 It is defined in s.2 Securities Act 1933, by reference to s.6 Securities Act 1933, where it says: "Any security may be registered with the Commission under the terms and conditions hereinafter provided, by filing a registration statement in triplate ...”.

16 Thomas Lee Hazen, Hazen's Treatise on the Law of Securities Regulations (6th edn Thomson West), $\$ 7.3[4]$.

17 Case law seems to indicate that investor can profit from the fraud on the market theory (which I will discuss in a moment).

18 See Dura Pharmacenticals v. Broudo, 544 U.S. 336 (2005) and Thomas Lee Hazen, Hazen's Treatise on the Law of Securities Regulations (6th edn Thomson West) $\mathbb{\$} 12.10$.

19 E.g. Donald Langevoort, 'Basic at Twenty: Rethinking Fraud-on-the-Market' [2009] Wis. L. Rev. 151, 157-58.

20 The first important case that introduced the reliance requirement was List v. Fashion Park, Inc., 340 F.2d 457 (2d Cir. 1965) ("The proper test is whether the plaintiff would have been influenced to act differently than he did act if the defendant had disclosed to him the undisclosed fact."). See also Huddleston v. Herman \& MacLean, 640 F.2d 534 (5 $5^{\text {th }}$ Cir. 1981) ("Reliance is a causa sine qua non, a type of "but for" requirement: had the investor known the truth he would not have acted."). Very critical on this "traditional” reliance: Merritt Fox, 'Demystifying Causation in Fraud-on-the-Market Actions' (2005) 60 Bus. Law. 507.

21 Basic v. Levinson, 485 U.S. 224 (1988). For a good (and critical) discussion of many 
Supreme Court allowed investors to show reliance indirectly with respect to securities traded on public and efficient markets. It suffices that an investor relied on the integrity of the market price. The idea behind this approach is that on a sufficiently efficient market, publicly available information - including misleading information - will be reflected in the market price. Therefore, an investor who purchases or sells shares relying on the integrity of the market price, indirectly relies on the material misrepresentation. Under certain conditions, investors can profit from a (rebuttable) presumption of reliance (see infra \$4.2). Briefly stated, the investor needs to show a material misstatement on an efficient market.

It is conceivable that an investor did not rely on the integrity of the market price. If this is the case, the investor has no claim under SEC Rule 10b-5. From the Basic decision, it is not completely clear what is meant by the integrity of the market price. It may refer to (i) a market price that corresponds to the underlying fundamental value of the security, or (ii) a market price that is the result of the publication of timely, non-misleading information. In the Basic case, the Supreme Court gives an example of nonreliance by referring to an investor who believed that a target company (Basic) that denied merger negotiations was in fact involved in such negotiations. If such an investor hence believed that the Basic stock was artificially underpriced, but sold his shares nevertheless because of other unrelated concerns, e.g., potential antitrust problems, or political pressures to divest from shares of certain businesses, he could not be said to have relied on the integrity of a price he knew had been manipulated. This example seems to illustrate that the Supreme Court has the second meaning of integrity in mind. ${ }^{22}$ However, justice White appears to favor the first meaning of integrity in his dissenting opinion. He mentions several examples of investors not relying on the integrity of the market price: a plaintiff who decides, months in advance of an alleged misrepresentation, to purchase a stock; one who buys or sells a stock for reasons unrelated to its price; one who actually sells a stock "short" days before the misrepresentation.

issues in Basic, see Donald Langevoort, 'Basic at Twenty: Rethinking Fraud-on-theMarket' [2009] Wis. L. Rev. 151.

22 See also 485 U.S. 224, 248 ("The court acknowledged that petitioners may (...) show that (...) an individual plaintiff traded or would have traded despite his knowing the statement was false" and 485 U.S. 224, 246-247 ("Who would knowingly roll the dice in a crooked crap game?”). However, a case can also be made that the Supreme Court uses the first meaning, looking at the references to lower court decisions and parliamentary documents. See 485 U.S. 224, 244 ("The market is (...) informing him that given all the information available to it, the value of the stock is worth the market price"; "(..) purchasers generally rely on the price of the stock as a reflection of its value"; 485 U.S. 224, 246 ("competing judgments of buyers and sellers as to the fair price of a security brings (...) about a situation where the market price reflects as nearly as possible a just price"). 
It is questionable whether these investors have not relied on the integrity of the market price, if one adopts the second meaning indicated above.

\subsection{German law}

In Germany, liability for misstatements in a prospectus can be based on general civil law (allgemein-zivilrechtliche Prospekthaftung) or the specific provisions in the Stock Exchange Act (BörsenGesetz). In practice, claims are usually based on the BörsenGesetz, so I will limit my discussion to these claims. German law requires a causal connection between the misleading statement and the investment decision (baftungsbegründende Kausalität). However, $\ 45$ of the BörsenGesetz contains a presumption on behalf of investors (see infra \$4.3). It is clear from that provision that a claim does not exist if the securities have not been acquired on the basis of the prospectus, or if the investor knew about the fraud when he acquired the security. According to legal scholars, the prospectus only needs to be mitursachlich for the acquisition, i.e. there must have been some causal connection. ${ }^{23} \mathrm{~A}$ causal connection is also accepted if the investment decision was based on a so called Anlagestimmung. This is not an exact legal term, but a psychological term. ${ }^{24}$ It refers to the fact that the publication of a prospectus can induce a sentiment that can persuade investors to buy the security. Finally, it seems that relying on an advisor may also establish the requisite causal connection. In the Securenta case $^{25}$, an advisor had misinformed the investor on the basis of a false prospectus. The Bundesgerichtshof accepted that there can be a causal connection between the false prospectus and the investment decision. Although the claim was based on general civil law ( $\$ 826$ Bürgerliches Gesetzbuch or BGB) in stead of the specific provisions of the BörsenGesetz, it may be argued that a similar argument can be made for a claim based on the latter provision. ${ }^{26}$

Secondary market liability claims may flow from a number of statutory provisions. First, there are the claims for violation of the obligation to disclose current reports (Ad-boc-Publizität). Liability of the issuer for unlawful delay in the ad hoc disclosure of insider information which directly applies to it, can be based on $\$ 37 \mathrm{~b}$ Wertpapierhandelsgesetz (WpHG). According to that provision, a claim is not available for an investor who knew of the insider

23 See e.g., Ulrich Ehricke, 'Deutschland' in Klaus Hopt \& Hans-Christoph Voigt (eds), Prospekt- und Kapitalmarktinformationshaftung (Mohr Siebeck 2005) 237, 240.

24 Norbert Bröcker, in Bank- und Börsenrecht für Studium und Praxis (CH Beck 2008) Rn. $94 \mathrm{f}$.

25 BGH 3.12.2007, II ZR 21/06.

26 As was done by the Advocate General Levinus Timmerman in his concluding argument before the World Online case. 
information at the time of the transaction. According to some German scholars, even if not knowing about the insider information was grossly negligent, this still does not exclude a claim. ${ }^{27}$ A liability claim for publication of misleading insider information which applies directly to the issuer, can be based on $\$ 37 \mathrm{c} \mathrm{WpHG}$. The claim is available for investors who relied on the truth of the insider information and - as in $\$ 37 \mathrm{~b}$ WpHG - did not know of the untruth. There is no statutory presumption of causation under these provisions. There is discussion among German scholars about the Schutzzweck

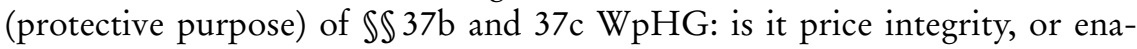
bling informed decision making? In the first case, reliance on the integrity of the market price could justify a claim based on the out of pocket loss (Differenzschaden $)^{28}$, i.e. the difference between the price at which the transaction occurred and the more favorable hypothetical price at which it would have occurred. A causal connection would only be required between the unlawful behavior and the investment decision at the given price. ${ }^{29}$ In the second case, a causal connection would be required between the unlawful behavior and the investment decision itself. In such cases, rescission or recessionary damages could be claimed. Claims for violation of the Ad-hoc-Publizität can also be based on general civil law (the Bürgerliches Gesetzbuch, BGB). An investor in principle needs to show a causal connection between the unlawful behavior and the investment decision. There is no statutory presumption on behalf of investors as in prospectus liability cases. A causal connection can only in exceptional cases be based on an Anlagestimmung (the concept developed for prospectus liability cases), because ad hoc statements are much more limited in scope than a prospectus, see infra $\$ 4.3$. The Bundesgerichtshof has explicitly rejected the idea that reliance on the integrity of the market price would be a sufficient causal connection, in fear of boundless expansion of liability. ${ }^{30}$

Secondary market liability claims can also flow from violations of the Regelpublizität (periodic financial reports) or non-mandatory publication of misleading statements. In such cases liability claims will have to be based on general civil law. Again, it seems the investor will have to show an actual causal connection between the unlawful behavior and the investment decision.

27 Hammen, in Bankrecht und Bankpraxis (Köln, Bank-Verlag) Rn. 7/788j (Oct. 2010).

28 Hammen, in Bankrecht und Bankpraxis (Köln, Bank-Verlag) Rn. 7/788m (Oct. 2010).

29 Schwark/Zimmer Kapitalmarktrechts-Kommentar (CH Beck 2010) \$\$ 37b, 37c WpHG Rn. 90.

30 BGH 4.6.2007, ZR 147/05. 


\subsection{Comparative conclusions and comments}

What to think of these Dutch, US and German approaches? I believe it is common to the legal systems of the Netherlands, the US, and Germany that a claim fails if an investor knew or believed that the company was misleading the market. It does not matter whether the claim deals with primary or secondary market liability. This result is not unacceptable, as the investor did not rely on the misstatement. ${ }^{31}$

The observation that a claim must fail for an investor in case of nonreliance, does not fully answer the question how direct the causal connection should be for a successful damage claim. To put it differently, what is "justifiable" reliance? Of particular interest is the case of an investor $\mathrm{X}$ who only in a very general way relied on the integrity of the market price, i.e. he did not read the prospectus or secondary market corporate statement, did not consult an advisor and had no knowledge of prevailing opinions (flowing from the misstatement) in the market. He may have bought the security because he just thought it would be a good investment, based on his own view of future developments, technical analysis or a computer algorithm. My guess would be that - at least in secondary market liability cases - many investors resemble this investor X. Let us further assume that the fraud distorted the market price at which the investor bought the security, so that such an investor can actually said to be harmed by the fraud. ${ }^{32}$

The Dutch World Online case may imply that such an investor X has no claim, because causation is considered absent (assuming that the issuer can prove this mere general reliance when rebutting the presumption of causation between the misstatement and the investment decision). In this sense, I feel that Dutch law is too strict. Why would one want to deprive such an investor X of his claim? Perhaps, one could argue that one may expect from an investor that he reads and investigates information which is published by the issuer. But this is out of line with reality, especially for retail investors. ${ }^{33}$ Another argument not to award damages to such an investor may be that the protective purpose of

31 Still, one may wonder whether this rule may not be too strict in some very specific cases. See e.g. Donald Langevoort, 'Basic at Twenty: Rethinking Fraud-on-the-Market' [2009] Wis. L. Rev. 151, $162 \mathrm{nt} 46$ who mentions the case of an index fund that was required to buy or sell stock in the index to stay consistent with its investment characterization. The index fund can be harmed if it buys or sells stock at a distorted market price. Should the law not allow it to recover damages?

32 If the law of a jurisdiction requires that the security must be held until after disclosure of the truth for a successful damage claim, I further assume that this is the case for investor $\mathrm{X}$.

33 See for Dutch law e.g. CM Grundmann-van de Krol, 'Het informatieparadigma voorbij' in Met Recht (Raaijkmakers-bundel) (Kluwer 2009) 165-179. 
disclosure rules (the Schutzzweck) is to enable investor to make an informed decision, not to promote price integrity. However, it will be far from clear that enabling the investor to make an informed decision is the only goal of disclosure rules in all jurisdictions. For example, in the Netherlands it is not. In my opinion, investors should be able to rely on the integrity of disclosure by issuers. I feel that it enhances confidence in the proper functioning of securities markets if investors are always protected, except for the case where they knew the statement was misleading at the moment of the transaction. ${ }^{34}$ One may argue that the rationale for such a rule is stronger for misstatements in a prospectus than for (secondary market) ad hoc misstatements, because a prospectus aims at directly selling securities ${ }^{35}$ and has a broader scope. However, assuming that the market price was actually distorted by the misstatement as we do here, would it not be better to allow a damage claim in secondary market cases as well? Not only would the investor be compensated for his actual losses, but allowing such claims may also deter issuers from publishing misleading statements. If one fears excessive ${ }^{36}$ litigation (as the German Bundesgerichtshof), other options are available to address these concerns, such as limiting or capping ${ }^{37}$ recoverable damages (see also infra $\$ 4.4$ ) and amending procedures for collective redress in misrepresentation cases. At least in the Netherlands, there are no signs or prospects of excessive litigation. Moreover,

34 In my opinion, uninformed reliance can even be justified on thin markets. In such cases, the more important question is whether there is a material misstatement or omission.

35 Some American scholars have argued that non trading issuers should not be liable for misstatements on the secondary market in violation of SEC Rule 10b-5. See John Coffee, 'Reforming the Securities Class Action: An Essay on Deterrence and its Implementation' (1996) 106 Colum. L. Rev. 1534, 1582-83 and Merritt Fox, 'Civil Liability and Mandatory Disclosure’ (2009) 109 Colum. L. Rev. 237.

36 Frank Easterbrook and Daniel Fischel, 'Optimal Damages in Securities Cases' (1985) 52 U. Chi. L. Rev. 611, 639-40 have argued that societal net harm as a result of securities fraud is smaller than the aggregate loss of injured investors, because the loss of an investor who pays an inflated price is offset by a gain of the investor who sells at the inflated price. Diversified investors have an equal chance of winning or losing from an ex ante perspective. Compensating ex post losers may over time result in systematic overcompensation of these diversified investors. Also, it has been argued that there is a "circularity problem". This means that a diversified investor does not benefit if he is compensated and continues to hold his stock in the company after the suit, because the compensation is paid by the company and therefore ultimately by the investor himself. The payment of the cost of counsel would result in an overall net loss. See James Cox \& Randall Thomas, 'Mapping the American shareholder litigation experience: a survey of empirical studies of the enforcement of the U.S. Securities Law' (2009) 6 ECFR 164, 175 ff for some counterarguments. Finally, because the company usually pays and corporate officials are often insured, securities fraud claims would not (sufficiently) succeed in deterring fraudulent behavior. See 121 Harv. L. Rev. 890, 896-897 and further references.

37 Donald Langevoort, 'Capping Damages for Open-Market Securities Fraud' (1996) 38 Ariz. L. Rev. 639. 
one should realize that proving a price distortion (I have simply assumed a price distortion here) is by no means an easy task for investors, so being investor-friendly with respect to the reliance requirement will not likely open the floodgates.

The US regime of s. 11 and s. 12(a)(2) Securities Act 1933 seems more favorable than Dutch law, as it (appropriately) only refuses to give a damage claim to an investor who knew the information was false. Our investor X will be protected. The US "fraud on the market" theory for secondary market claims based on SEC Rule 10b-5 is less clear on the position of investor X. The concept of reliance on the integrity of the market price is somewhat unclear in the US, as I have illustrated above. If it means that an investor has a claim if he relied on the fact that the market price reflects timely, non-misleading information, I believe the "fraud on the market" theory is optimal (as investor $\mathrm{X}$ would be protected). However, if reliance on the integrity of the market price means that an investor must have believed that the market price corresponded to the underlying fundamental value of the security, I believe it is too strict. I cannot think of convincing reasons why an investor should have believed that the market price corresponds to the underlying fundamental value. On the contrary, usually investors will buy a security because they believe that the security is undervalued and sell because they believe it is overvalued. This is how the securities markets work.

How does German law deal with the position of the investor X? First, let us have a look at prospectus liability claims based on the BörsenGesetz. Looking beyond the way the burden of proof is allocated, it seems German law will deprive investor $\mathrm{X}$ of his claim. Apparently, the investor must have read the prospectus, relied on an advisor, or relied on an Anlagestimmung. However, it should be admitted that in practice issuers will rarely be able to rebut the presumption of causation. ${ }^{38}$ The position of investors with respect to (secondary market) liability claims may be difficult. Not only can they not profit from a statutory presumption of causation, but an Anlagestimmung may not easily be assumed. This would imply that the most indirect form of reliance by investor $\mathrm{X}$ would not provide a successful damage claim. We have seen that the Bundesgerichtshof has explicitly rejected reliance on the integrity of the market price as a sufficient basis for causality under $\$ 826$ BGB in fear of excessive litigation. As I have argued above, this line of reasoning is not very appealing. Only if it is true, as German scholars have argued, that reliance on the integrity of the market price is acceptable at least with respect to claims under $\$ \$ 37 \mathrm{~b}$ and 37c WpHG (allowing a damage claim based on the out of pocket loss), investor X would be protected.

38 Baumbach/Hopt, Handelsgesetzbuch (CH Beck 2010) BörsG \45 Rn. 2. 


\section{Effective protection (II): applying a presumption of proof}

\subsection{Dutch law}

Under Dutch law, an injured investor in principle has the burden of proving cause in fact. This applies to both primary market and secondary market liability claims. It is not required that there be $100 \%$ certainty that the harm is caused by misrepresentation. Usually it is assumed that a reasonable degree of certainty is sufficient. Moreover, the judge could use techniques such as presumptions to relieve the investor's burden of proof.

As we have seen, the Dutch Supreme Court requires proof of a causal connection between the misstatement and the investment decision in the World Online decision ${ }^{39}$ on prospectus liability. It acknowledges that proof of this causal connection is problematic, because an investor will in general be guided by a multitude of considerations. Moreover, often it will not be possible to show that the investor actually took notice of the misleading statement, and less so that he was actually influenced by it. The influence can also have been indirect, because the investor relied on advices or prevailing opinions in the market, which in turn were brought into existence by the misleading statement. According to the Supreme Court, these problems of proof may have as a result that the protection of investors which was envisioned by the Prospectus Directive $^{40}$ in practice becomes illusory. The Supreme Court notes that the preamble of the Prospectus Directive explicitly mentions protection of (potential) investors as one of the objectives. Moreover, the Prospectus Directive requires a prospectus to contain all information necessary to enable investors to make an informed assessment of the position of the company. Thus, the court argues that strict compliance with this directive and the national implementing rules may be required. The Supreme Court also notes that the Prospectus Directive does not harmonize the civil liability of the issuer for misleading statements in the prospectus, but does require member states to make sure that national statutory provisions on civil liability apply to those who are responsible for the information in the prospectus (art. 6(2) Prospectus Directive). Thus, an effective protection of investors according to the rules of national law is required. With a view to this effective protection and taking into account the intended protection of (potential) investors by the Prospectus provisions, the Supreme Court relieves the burden of proof. This is done by accepting as a "point of departure" (which I will call a presumption for simplicity) that a causal connection between the misleading prospectus and the investment decision exists. The Supreme Court also says that this means that

39 Hoge Raad 27 november 2009, JOR 2010/43 (VEB e.a./World Online e.a.).

40 Council Directive (EC) 2003/71 [2003] OJ L345/64. 
but for the fraud the investor "would not - or in case of purchase on the secondary market: not or not under the same conditions - have entered into the purchase of the securities." Apparently, the court sees a distinction between what primary and secondary market purchasers would have done, but for the misstatement. ${ }^{41}$

According to the Supreme Court, the judge may conclude that the point of departure does not apply. He may reach this conclusion based on the arguments that have been put forward by the parties (whereby the facts underlying these arguments should be made plausible by the most appropriate party), the nature of the misleading statement(s) and further available information. For example, the Supreme Court argues that the presumption does not apply if the investment decision was taken before the misleading statement became public. Moreover, the Supreme Court explains that nonreliance is more likely for a professional than for a nonprofessional investor, given the professional's knowledge of and experience with analyzing information and the relevant market.

Currently, it is not certain whether this approach may extend beyond prospectus liability claims to other secondary market liability claims. As we have seen, the Supreme Court justifies the presumption by referring to the Prospectus Directive and the need for effective protection of investors. I would expect the court to rule in a similar way when issuers violate periodic disclosure requirements. In the preamble (nr. 1) of the Transparency Directive ${ }^{42}$ that contains such requirements, it is noted that " $[t]$ he disclosure of accurate, comprehensive and timely information ... builds sustained investor confidence and allows an informed assessment ... This enhances both investor protection and market efficiency.". Investor protection is thus considered important by the European legislator not only when a prospectus is issued, but also afterwards. The Transparency Directive moreover provides that member states shall ensure that their laws, regulations and administrative provisions on liability apply to the issuers, or the persons responsible within the issuers (art. 7). Thus, one could again argue that an effective protection of investors is required according to the rules of national law. ${ }^{43}$ Finally, the problems of proof that the investor faces in secondary market liability cases with respect to the causal connection between the misstatement and the investment decision, are no different than in prospectus liability cases. These problems of proof may have as a result that the protection which was envisioned by the Transparency

41 This may have consequences for the proper calculation of damages, but this issue is not settled under Dutch law, so I will not discuss it further.

42 Council Directive (EC) 2004/109 [2004] OJ L390/38.

43 However, it should be admitted that article 7 of the Transparency Directive does not refer to civil liability as the Prospectus Directive does, which weakens the argument. 
Directive in practice becomes illusory. The line of reasoning that was used by the Supreme Court for prospectus liability cases therefore extends quite naturally to claims with respect to misleading periodic reports.

Finally, one may wonder whether the line of reasoning by the Dutch Supreme Court extends to claims for violation of the obligation of (immediate) ad hoc disclosure of inside information which directly concerns the issuer. In the Netherlands, civil liability is possible in such cases. This obligation is based in part on the Market Abuse Directive ${ }^{44}$, which aims to combat insider trading. The Dutch legislator accepts a wider aim, namely the promotion of transparency and price integrity. Again, one could argue that on these grounds the Supreme Court may adopt a similar presumption of reliance. The Supreme Court may also accept a presumption for a different reason. It is difficult in omission cases - nondisclosure of a material fact - for an investor to show that he relied on what was not said. As we will see below in US securities law, a presumption of reliance applies in pure omission cases there. The Dutch Supreme Court may also be susceptible to this line of reasoning.

\subsection{US securities law}

As we have seen, if a damage claim is based on s.11 or 12(a)(2) Securities Act 1933, reliance is not an element of a claim. The defendant may try to show nonreliance, though. In this respect, US securities law is very investor-friendly.

In case of misleading statements on the secondary market, investors will usually want to sue issuers on the basis of SEC Rule 10b-5. Reliance is an element of a claim, i.e. the investor needs to show reliance. Two exceptions have been created in the jurisprudence of the US Supreme Court, in the form of presumptions of proof. ${ }^{45}$

\section{Failure to disclose}

First, in cases involving primarily a failure to disclose, positive proof of reliance is not a prerequisite to recovery. This was decided in Affiliated Ute $v$. United States ${ }^{46}$. All that is necessary is that the facts witheld be material in the sense that a reasonable investor might have considered them important in the making of his decision. This obligation to disclose and this withholding of a material fact establish the requisite element of causation in fact. The rationale

44 Council Directive (EC) 2003/6 [2003] OJ L96/16.

45 This was affirmed in Stoneridge Investment Partners, LLC v. Scientific Atlanta, Inc. et al, 128 S.Ct. 761, 769 (2008).

46406 U.S. 128 (1972). 
for his decision is that it is difficult to prove a "speculative negative", namely that the investor relied on what was not said. An appellate court has later decided that the Affiliated Ute presumption should not be applied to cases that allege both misstatements and omissions unless the case can be characterized as one that primarily alleges omissions. ${ }^{47}$

\section{Frand on the market presumption of reliance}

As we have seen above, in Basic v. Levinson ${ }^{48}$, the Supreme Court allowed investors to show reliance indirectly, by their reliance on the integrity of the market price. Transactions on modern securities markets differ significantly from face-to-face transactions. Analyzing the way active securities markets function, the Supreme Court argues that a rebuttable presumption of reliance can be adopted if an investor alleges and proves: (1) that the defendant made public misrepresentations; (2) that the misrepresentations were material; (3) that the shares were traded on an efficient market; and (4) that the plaintiff traded the shares between the time the misrepresentations were made and the time the truth was revealed. The rebuttable presumption of reliance adopted in Basic was essential to facilitate securities class actions in the US, because requiring individualized proof of reliance would effectively bar class actions from proceeding. It has allowed investors to act as a "private attorney general" 49 . Soon after Basic, the number of fraud on the market suits rose dramatically, which resulted in strong criticism on securities class action lawsuits. It led US Congress to adopt the Private Securities Litigation Reform Act of 1995 (PSLRA)..$^{50}$ However, Basic's presumption of reliance was left intact.

It seems that the background for the fraud on the market theory is the efficient market hypothesis (EMH). ${ }^{51}$ Simply put, the EMH posits that an ordinary investor cannot make trading profits on the basis of new information, because that information is already reflected in the market price. ${ }^{52}$ In Re PolyMedica

47 Binder v. Gillespie 184 F.3d 1059, 1063-1064 (9th Cir. 1999).

48485 U.S. 224 (1988).

49 The term was coined in Associated Industries of New York State, Inc. v. Ickes, 134 F.2d 694, 704 (2d Cir. 1943) ("Such persons, so authorized, are, so to speak, private Attorney Generals.”); See also William Rubenstein, 'On What a "Private Attorney General” Is And Why It Matters' (2004) 57 Vand. L. Rev. 2129.

50 Thomas Lee Hazen, Hazen's Treatise on the Law of Securities Regulations (6th edn Thomson West) $\mathbb{\$} 12.15$.

51 This theory originates from Eugene Fama, 'Efficient Capital Market: A Review of Theory and Empirical Work’ (1970) 25 Journal of Finance 383.

52 There are three major versions of the hypothesis: "weak", "semi-strong”, and "strong”. Weak EMH claims that prices on traded securities reflect all past publicly available information. Semi-strong EMH claims both that prices reflect all publicly available 
Securities Litigation ${ }^{53}$ it was decided by the First Circuit, following finance literature, that an efficient market is "one in which the market price of the stock fully reflects all publicly available information". With the words "fully reflects", the court means that the market incorporates new information in the market price with a certain speed ("informational efficiency"), not that the information is incorporated both quickly and correctly according to finance theory ("fundamental efficiency"). The required speed is such that ordinary investors cannot make trading profits on the basis of such information. The appellate court's definition of an efficient market and its application in the case have been (sharply) criticized, for being too strict. ${ }^{54}$ Moreover, legal scholars have criticized the requirement of an efficient market itself as a precondition to the application of the fraud on the market presumption of reliance. ${ }^{55} \mathrm{I}$ will return to this point in the comparative conclusions below.

There has been controversy in the US over the Fifth Circuit's decision in Oscar Private Equity Investments v. Allegiance Telecom ${ }^{56}$. It was argued by the Fifth Circuit that in securities class actions, "loss causation" (i.e. a drop in the value of the stock after disclosure of the truth ${ }^{57}$ ) needs to be shown at the class certification phase by a preponderance of all admissible evidence before a presumption of reliance can be adopted. ${ }^{58}$ Commentators and other courts have argued that this decision is out of line with Basic v. Levinson. ${ }^{59} \mathrm{I}$ believe that is true.

information and that prices instantly change to reflect new public information. Strong EMH additionally claims that prices instantly reflect even hidden or "insider" information. There is evidence for and against the weak and semi-strong EMHs, while there is powerful evidence against strong EMH. The EMH has come under criticism. See Lynn Stout, 'The Mechanisms of Market Inefficiency: An Introduction to the New Finance' (2003) 28 J. Corp. L. 635, 639. See also Frederick Dunbar and Dana Heller, 'Fraud on the Market Meets Behavioral Finance' (2006) 31 Del. J. Corp. L. 455.

53 See In re PolyMedica Securities Litigation, 432 F.3d 1 (1 ${ }^{\text {st }}$ Cir. 2005).

54119 Harv. L. Rev. 2284 with further references.

55 See Donald Langevoort, 'Basic at Twenty: Rethinking Fraud-on-the-Market' [2009] Wis. L. Rev. 151, 160-61.

56487 F.3d 261 (5 th $^{\text {th }}$ ir. 2007). It was followed up by Luskin v. Intervoice-Brite Inc., 261 Fed.Appx. 697 (5 $5^{\text {th }}$ Cir. 2008).

57 See e.g., Glaser v. Enzo Biochem, 464 F.3d 474 (4th Cir. 2006) ("It is only after the fraudulent conduct is disclosed to the investing public, followed by a drop in value of the stock, that the ... investor has suffered a "loss" that is actionable after the Supreme Court's decision in Dura"). The court refers to Dura Pharmacenticals v. Broudo, 544 U.S. 336 (2005).

58 This is motivated by that court by pointing out that the efficient market doctrine "facilitates an extra ordinary aggregation of claims" and the certification has "in terrorem power".

59 See e.g. Donald Langevoort, 'Basic at Twenty: Rethinking Fraud-on-the-Market' [2009] Wis. L. Rev. 151; In re LDK Solar Securities Litigation, 2009 WL 196396 (N.D. Cal. 
The presumption of reliance can be rebutted. According to the Supreme Court in Basic, "any showing that severs the link between the alleged misrepresentation and either the price received (or paid) by the plaintiff, or his decision to trade at a fair market price, will be sufficient to rebut the presumption of reliance". One example mentioned by the Supreme Court is that the market price would not have been affected by the misrepresentations because market makers were privy about the truth. Another example is that news credibly enters the market and dissipated the effects of the misstatements, so that those who trade shares after the corrective statements would have no direct or indirect connection with the fraud. Finally, the Supreme Court argues that defendants could rebut the presumption of reliance as to investors who would have divested themselves of their shares without relying on the integrity of the market. I have already discussed this example above.

The fraud on the market theory cannot be applied on the primary market, as it is not considered an efficient market. ${ }^{60}$ Some courts have created other constructions $^{61}$, but these will not be discussed here. It seems logical that investor will make a damage claim based on s. 11 or 12(a)(2) Securities Act 1933 in such cases, so that reliance is not an element of the claim.

\subsection{German law}

The BörsenGesetz $(\$ 45)$ contains a presumption of a causal connection between the misleading statement and the investment decision (haftungsbegründende Kausalität) on behalf of investors. It is clear from that provision that a claim does not exist if the securities have not been acquired on the basis of the prospectus, or if the investor knew about the fraud when he acquired the security. As we have seen, an indirect causal connection is accepted in German law. Therefore, the presumption is not rebutted if the prospectus was merely mitursachlich for the acquisition. ${ }^{62}$ If it was not mitursachlich, for example when the investor did not know of the prospectus, then the presumption is

2009), nt 6. The Supreme Court is expected to give its opinion on the issue in the case Erica P. John Fund, Inc. v. Halliburton Co., which was still pending at the time this paper was finished.

60 Initial Public Offering Securities Litigation, 471 F.3d 24, 42-43 (2d Cir. 2006) ("in an IPO there is no well-developed market in offered securities"). In the subsequent proceedings, the district court held that an efficient market can arise shortly after the IPO. See In re Initial Public Offering Securities Litigation, 544 F.Supp.2d 277, 295-296.

61 E.g. the fraud-created-the-market theory. See e.g. Shores v. Sklar, 844 F.2d 1485 (11 ${ }^{\text {th }}$ Cir. 1988); Joseph v. Wiles, 223 F.3d 1155 (10th Cir. 2000).

62 See e.g., Ulrich Ehricke, 'Deutschland' in Klaus Hopt \& Hans-Christoph Voigt (eds), Prospekt- und Kapitalmarktinformationshaftung (Mohr Siebeck 2005) 239-240. 
rebutted. Indirect reliance is also accepted on the basis of an Anlagestimmung (investment mood), making it more difficult for the issuer to rebut the presumption. Case law has not clearly established when an Anlagestimmung can be assumed, but it is probably limited to the six month period after admission of the securities to the exchange. ${ }^{63}$ Finally, the defendant might not succeed in rebutting the presumption if an investor relied on an advisor, as we have seen above in the Securenta case ${ }^{64}$.

There are no statutory presumptions with respect to causation in secondary market liability cases. In its ComROAD decisions ${ }^{65}$, the Bundesgerichtshof argued that the concept of an Anlagestimmung which is used in prospectus liability cases to relieve the burden of proof cannot be carried over to tort liability under $\$ 826 \mathrm{BGB}$ to create a presumption. In the ComROAD case, grossly incorrect current reports had been published. The question was whether causality between the current reports and the investment decision of the injured investor could be established. The court observes that the investment decision of a potential share purchaser is an individual choice whose composition is not open to observation, but that is influenced by a multiplicity of rational and irrational factors, in particular also by speculative elements. According to the court, there can be no circumstantial evidence (Anscheinsbeweis) which creates a specific presumption that people will have a certain type of comportment in certain situations. Current reports usually deal with new information which can be relevant for a swift individual investment decision, but they are as a rule not suited to create an Anlagestimmung. Nevertheless, the court does not exclude that in a certain case the positive signals flowing from a current report can create a real Anlagestimmung. However, even in such cases one may not use a mode of observation that rests on a schematic, fixed period to form a judgment on its nature and duration. According to the Bundesgerichtshof, the lower court had assumed an Anlagestimmung on insufficient grounds. The assumption was not based on a concrete and thorough market analysis of the ComROAD shares. The Bundesgerichtshof could not accept the assumption by the lower court that an Anlagestimmung was present for two years after the introduction of the shares, given the high volatility of the shares. The Bundesgerichtshof also points at the many factors that influence the share price, by referring to its Infomatec decision ${ }^{66}$. In that decision, the court argued that the effect of positive information will decrease after its publication. In any case, an Anlagestimmung will end when in the course of time other factors which are relevant for the valuation of the securities become more important. The court gives the example of a significant change in the stock market index, the state of

63 Baumbach/Hopt, Handelsgesetzbuch (CH Beck 2010) BörsG $\$ 44$ Rn. 9 and $\ 45$ Rn. 2.

64 BGH 3.12.2007, II ZR 21/06.

65 BGH 4.6.2007, II ZR 147/05 and II ZR 173/05.

66 BGH 19.7.2004, II ZR 217/03, BGHZ 160, 134. 
the economy, or new company information (such as annual, half-yearly or quarterly accounts, or a new ad hoc statement).

German scholars have argued that a particular presumption can be justified with respect to misleading or omitted current reports under $\$ \int 37 \mathrm{~b}$ and $37 \mathrm{c}$ WpHG, namely that investors relied on the fact that all the information that should be disclosed is completely reflected in the market price. Such reliance on the integrity of the market price could then justify a claim based on the out of pocket loss (Differenzschaden). ${ }^{67}$ This line of reasoning appears to be inspired by the American fraud on the market theory.

\subsection{Comparative conclusions and comments}

Prospectus liability cases

Dutch, US and German law all relieve investors with respect to the burden of proving a causal connection between a misleading prospectus and the investment decision. Where there are statutory presumptions of proof in the US and Germany, there is a judicial presumption in the Netherlands.

Although all three jurisdictions use presumptions, there may be differences in how issuers can rebut the presumption in these jurisdictions. First, we need to remember that there could be differences in how direct reliance should be for a successful damage claim (see supra $\$ 3$ ). Where in the US any form of direct or indirect reliance is sufficient, this may not be the case in the Netherlands and Germany, where an investor needs to have relied on opinions in the market (Netherlands), an Anlagestimmung (Germany) or an advisor (Netherlands and Germany). In my opinion, the American way is to be preferred (see supra $\$ 3.4$ ). A second difference is that in the Netherlands, the Supreme Court has decided that the presumption may be rebutted for professional investors more quickly than for retail investors. It is uncertain to what extent such a rule also applies in the US and Germany. Nevertheless, the intuition seems to make sense.

\section{Secondary market cases}

Differences between the three jurisdictions appear to be larger for lawsuits alleging misleading statements or omissions on the secondary market. As we have seen above, there are no statutory presumptions available in any of the jurisdictions, so the courts have had to rely on their own wits.

67 Hammen, in Bankrecht und Bankpraxis (Köln, Bank-Verlag) Rn. 7/788m and 7/790a (Oct. 2010). 
First, there is a distinction in the US between pure omission cases and other cases. A presumption of reliance is available for investors in these omission cases. In other cases, the US Supreme Court uses the fraud on the market presumption of reliance. The distinction between pure omission cases and other cases is not explicitly made in Germany and the Netherlands. However, I feel that the intuition behind the presumption in omission cases is convincing.

One of the most remarkable conditions for the fraud on the market presumption of reliance to apply, is that investors need to show that the market is (informationally) efficient. Such an approach is unknown in the Netherlands and Germany. In my opinion, this focus by (lower) US courts on market efficiency is ungainly. Requiring proof of market efficiency severely complicates the proceedings. It is very difficult or even impossible to test whether the market price fully reflects all publicly available information. Moreover, market efficiency as defined by economists is not required for the price of a listed security to be influenced by misleading statements. ${ }^{68} \mathrm{It}$ that sense, following the US example does not seem attractive for European jurisdictions; it may be at odds with the European requirement of effective investor protection.

One may wonder how the German approach relates to the fraud on the market theory. In Germany, the courts have been conservative with respect to damage claims. The Bundesgerichtshof has explicitly rejected the fraud on the market theory for claims under $\$ 826$ BGB. We have seen that reliance on an Anlagestimmung (investment mood) cannot easily be accepted. Only for purchases and sales following shortly after a misleading current report, there appears to be some likelihood that investors can show reliance on an Anlagestimmung. It has been questioned whether the theory of the Anlagestimmung is really suited for relieving the burden of proof in case of misleading ad hoc statements. ${ }^{69}$ According to some scholars, a presumption should be available that investors relied on the integrity of the market price under $\mathbb{\int} \$ 37 \mathrm{~b}$ and $37 \mathrm{c}$ WpHG. In such cases, investors could then probably recover out of pocket

68 Eckstein v. Balcor Film Investors, 8 F.3d 1121 (7th Cir. 1993) ("Prices of even poorly followed stocks change in response to news ...”). See also Brad Barber, Paul Griffin \& Baruch Lev, 'The fraud-on-the-market theory and the indicators of common stocks' efficiency' (1994) 19 J. Corp. L. 285, 290-91; RJ Gilson and RH Kraakman, 'The Mechanisms of Market Efficiency’ (1984) 70 Va. L. Rev. 549, 558-59; Donald Langevoort, 'Basic at Twenty: Rethinking Fraud-on-the-Market' [2009] Wis. L. Rev. 151, 161 and 186 ("It is distortion- not metrics of efficiency-that is ultimately important").

69 Klaus Hopt and Hans-Christoph Voigt, 'Grundsatz- und Reformprobleme der Prospekt- und Kapitalmarktinformationshaftung' in Klaus Hopt and Hans-Christoph Voigt (eds), Prospekt- und Kapitalmarktinformationshaftung (Mohr Siebeck 2005) 138. 
losses. ${ }^{70}$ If a strict form of market efficiency as in the US is not required, I believe such an approach could be acceptable.

The line of reasoning by the Dutch Supreme Court in prospectus liability cases may provide a third way to deal with causation in lawsuits involving a misstatement or omission on the secondary market. It may be argued that the problems of proof and the requirement of effective protection of investors in the Transparency Directive and the Market Abuse Directive merit the adoption of a presumption of causation between the fraud and the investment decision. ${ }^{71}$ One could imagine that - just as in prospectus liability cases - a presumption would be adopted if a material misstatement or omission is shown by investors. It is not necessary that the presumption is a good reflection of how investment decisions are actually taken, as the German Bundesgerichtshof seems to require in the ComROAD decision (see supra $\$ 4.3$ ). It could just be an act of juristic grace. ${ }^{72}$

Perhaps one may fear that such an approach would be too liberal and open the door to an undesirable amount of securities litigation, especially when there are procedures for the collective redress of investment losses. I think this fear is legitimate. Securities litigation should not work as an insurance policy for investors. However, the extent to which this fear is justified may also depend on the proper measure of legally recoverable damages (and the way to prove damages). For example, if legally recoverable damages are curbed as in the United States (Rule 10b-5 cases) to the residual drop in value of the stock after disclosure of the truth ${ }^{73}$, this would limit the amount of the damage claim.

I would favor an approach that is a little stricter for investors. In my opinion, a presumption of causation between the unlawful behaviour and the investment decision could be adopted if investors show with a reasonable degree of certainty that the market price was distorted by the misstatement or omission. In such cases it is likely that sophisticated investors have actually been misled, so it seems (factually or at least normatively) acceptable to apply the presumption that there is a causal connection between the unlawful behavior and the invest-

70 However, it not completely clear to what extent the Schutzzweck of ad hoc disclosure rules is indeed price integrity, instead of enabling informed decision making.

71 Assuming that the national courts continue to demand such a causal connection. As I have argued above, this is not necessary if the investor claims out of pocket losses and the law would allow recovery of such losses.

72 Donald Langevoort, 'Basic at Twenty: Rethinking Fraud-on-the-Market' [2009] Wis. L. Rev. 151, 161.

73 Glaser v. Enzo Biochem, 464 F.3d 474 (4th Cir. 2006) ("It is only after the fraudulent conduct is disclosed to the investing public, followed by a drop in value of the stock, that the ... investor has suffered a "loss" that is actionable after the Supreme Court's decision in Dura"). 
ment decision of the individual investor. ${ }^{74}$ This approach is probably more liberal than the approach of the German courts from the investor's perspective, for there may be cases where a presumption can be used even if there is no clear Anlagestimmung (e.g. omission cases). It is not necessarily stricter than the US approach in Basic v. Levinson. Investors need not show that the market was efficient, because the price can also be influenced on an inefficient market. My approach differs somewhat from the rule in $\mathrm{Oscar}^{75}$. In that case, it was required of investors to show a drop in the value of the stock after disclosure of the truth ("loss causation") before a presumption of reliance can be adopted. As legal scholars in the US have observed, there may be clear indications that the market price was influenced by the fraud, but it may be hard to show exactly when the fraud dissipated the price. ${ }^{7}$ Therefore, requiring evidence of loss causation before a presumption of reliance/causation is adopted, may be too strict.

\section{Conclusion}

I have addressed the requirement of causation in misrepresentation cases, specifically the causal connection between the misstatement and the investment decision. Proving this causal connection is often problematic, which raises the question how investors can be effectively protected without inviting excessive litigation. The analysis was conducted from the perspective of Dutch, US and German law, for both primary and secondary market liability claims.

A first question that has been analyzed is how direct the causal connection should be for a successful damage claim. In other words, what is "justifiable" reliance? Is it required that an investor has read and relied on the misleading statement, or is it sufficient that he relied on advices, opinions in the market or even the integrity of the market price? We have seen that indirect forms of reliance are accepted in all three jurisdictions, but the Netherlands and Germany do not seem to allow reliance on the integrity of the price as the US does. ${ }^{77}$ I have argued that investors should be able to rely on the integrity of disclosure by issuers (on both the primary and secondary market), and hence

74 I do not argue here that applying such a presumption necessarily implies the availability of a rescissionary remedy for the investor. The scope of liability may be more limited, taking into account the protective purpose of disclosure rules and the nature and remoteness of the damage.

75487 F.3d 261 (5 $5^{\text {th }}$ Cir. 2007).

76 See the dissenting opinion by Judge Dennis in the Oscar case, and Donald Langevoort, 'Basic at Twenty: Rethinking Fraud-on-the-Market' [2009] Wis. L. Rev. 151, 186.

77 There may be an exception in Germany for claims under $\$ \$ 37 \mathrm{~b}$ and $37 \mathrm{c}$ WpHG. 
also on the integrity of the market price (see supra $\$ 3.4$ ). Such reliance could justify a damage claim based on the out of pocket loss. ${ }^{78}$

Another question that has been analyzed is whether and under what conditions a presumption of proof should be used on behalf of investors. We have seen that the Dutch Supreme Court, recognizing problems of proof, has accepted a presumption on favorable terms for prospectus liability cases. A material misstatement or omission is sufficient to activate the presumption. The adoption of the presumption was in part motivated by referring to the Prospectus Directive which requires an effective protection of investors. We have seen that the line of reasoning of the court extends quite naturally to claims dealing with the violation of ad hoc disclosure obligations and misleading periodic reports on the secondary market. These disclosure obligations are based on European directives requiring effective investor protection as well. One may wonder whether it is too investor-friendly if this approach is extrapolated to lawsuits alleging a misstatement or omission on the secondary market, inviting excessive litigation. No efficient market would be required as under the US fraud on the market theory. Nor would there have to be an Anlagestimmung (the German concept of an investment mood). I have argued for a stricter approach (see supra $\$ 4.4$ ), implying that a presumption may be adopted if investors show with a reasonable degree of certainty that the market price was distorted by the misstatement or omission. Under such a condition, the difficulties with the concept of an efficient market as in US case law are avoided. The concept of an Anlagestimmung, which according to some German scholars is not very suitable for relieving the burden of proof in lawsuits alleging misleading ad hoc statements, need not be used. But as a showing of price distortion is not always easy, excessive litigation can be avoided.

78 I do not argue here that the out of pocket loss is the proper scope of liability, which could be curbed further. 